A $\mathrm{C} \cup$ Rec. Nat. Prod. 15:1 (2021) 65-70

records of natural

products

\title{
Chemical Composition, Antioxidant and Antimicrobial Activities of Essential Oil from the Leaves of Lindera fragrans Oliv. Chunyan Du@ ${ }^{1}$, Yanan Li $\odot{ }^{1}$, Junting Fan $\odot^{2}$, Rui Tan $\odot{ }^{* 1}$ and Hezhong Jiang
}

\author{
${ }^{1}$ School of Life Science and Engineering, Southwest Jiaotong University, Chengdu, P.R. China \\ ${ }^{2}$ Department of Pharmaceutical Analysis, School of Pharmacy, Nanjing Medical University, Nanjing, \\ P.R. China
}

(Received April 19, 2020; Revised June 16, 2020; Accepted July 13, 2020)

\begin{abstract}
The chemical composition of the essential oil obtained by hydrodistillation from the leaves of Lindera fragrans Oliv. was determined by gas chromatography (GC) and gas chromatography coupled with mass spectrometry (GC-MS). Sixty two compounds accounting $76.45 \%$ of the essential oil were identified. The main constituents found to be spathulenol (27.63\%), ledol (6.81\%), $\beta$-caryophyllene $(4.01 \%),(+)$-cis-limonene oxide (3.69\%), $\alpha$-cadinol (3.24\%). The disc diffusion method on antimicrobial activities revealed that it has remarkable inhibition effect against Escherichia coli (CP009072.1), Staphylococcus aureus (CP009361.1), Pseudomonas aeruginosa (CP015117.1) and Candida albicans (FJ159643.1). Antioxidant capacity of the essential oil was evaluated by 2,2'-diphenyl-1-picrylhydrazyl (DPPH), 2,2-azino-bis(3-ethylbenzothiazoline-6-sulfonic acid) (ABTS) and $\beta$ - carotene bleaching assay, and it did not show effective antioxidant activity.
\end{abstract}

Keywords: Lindera fragrans Oliv.; essential oil; antimicrobial; antioxidant; GC-MS; spathulenol. (C) 2020 ACG Publications. All rights reserved.

\section{Plant Source}

The leaves of the Lindera fragrans Oliv. ( $2 \mathrm{~kg}$ ) were collected from Jiange County $\left(32^{\circ} 17^{\prime}\right.$ 15.80" N and $105^{\circ} 31^{\prime} 29.16^{\prime \prime}$ E; Alt. 540 m), Sichuan Province, China, in April 2016. The species was identified by Associate Prof. Liang-Ke Song (School of Life Science and Engineering, Southwest Jiaotong University, China), and a voucher specimen (SWJTU-201604) was deposited at the Herbarium of School of Life Science and Engineering, Southwest Jiaotong University, China.

\section{Previous Studies}

The genus Lindera (Lauraceae) is an important natural source for tradional medicinal and perfume applications, and it grows in the temperate zone of Asia and North America. The genus

\footnotetext{
*Corresponding author: E- Mail: jianghz10@ sina.com ; tanrui@home.swjtu.edu.cn
} 
consists of approximately 100 species in all around of the world [1]. Lindera fragrans Oliv., widely distributed in Sichuan and Yunnan Province of China, is used in folk medicine for treatment of gastric pain and gastric ulcer. The leaves of L. fragrans are also used as mosquito repellent in Sichuan Province [2].

Secondary metabolites of several species of the genus such as, Lindera setchuenensis Gamble [3], Lindera nacusua (D. Don) Merr. [4], Lindera erythrocarpa [5], Lindera aggregate [6], Lindera glauca (Sieb. et Zucc.) [7, 8], Lindera neesiana Kurz [9], and Lindera chunii Merr. [10] were reported. While the leaf essential oil of L. strychnifolia can inhibit the proliferation of HepG2 cell [11, 12], essential oil of L. umbellata and its component linalool induced apoptosis and differentiation of HL-60 cell [13]. However, no related report was found about the chemical composition and bioactivities of the essential oil of $L$. fragrans, which inspired us to investigate chemical composition and antimicrobial activities of the essential oil L. fragrans.

\section{Present Study}

The essential oil was obtained by hydrodistillation from the leaves of the species and yield of the process were determined as $0.85 \%(\mathrm{v} / \mathrm{w})$ on the basis of the oil volume and the dry weight of the plant material used (Method employed for GC and GC-MS were given in supporting information S1). The analyses reveal the presence of 101 peaks but 62 compounds could be identified, which accounted for $76.45 \%$ of the total peak area. The main compounds were determined as spathulenol $(27.63 \%)$, ledol $(6.81 \%), \beta$-caryophyllene $(4.01 \%),(+)$-cis-limonene oxide $(3.69 \%), \alpha$-cadinol $(3.24 \%), \beta$ eudesmol (2.55\%), (-)-humulene epoxide II $(2.32 \%)$, caryophyllene oxide $(2.27 \%)$ and $\delta$-cadinol $(2.05 \%)$. The detailed list of the identified compounds are presented in Table 1.

Table 1. Composition of the essential oil from the leaves of L. fragrans

\begin{tabular}{llcccc}
\hline $\mathbf{N o}^{\#}$ & Compound & $\mathbf{R I}$ & $\mathbf{R I}$ & Area $^{\mathbf{c}} \mathbf{( \% )}$ & Identification $^{\mathbf{2}}$ \\
\hline 1 & (Z)-3-Hexen-1-ol & 875 & 875 & 0.06 & $\mathrm{MS}^{\mathrm{b}}, \mathrm{RI}^{\mathrm{a}}$ \\
2 & Linalool & 1094 & 1096 & 0.09 & $\mathrm{MS}^{\mathrm{b}}, \mathrm{RI}^{\mathrm{a}}$ \\
3 & Fenchol & 1118 & 1114 & 0.04 & $\mathrm{MS}^{\mathrm{b}}, \mathrm{RI}^{\mathrm{a}}$ \\
4 & (-)-trans-Pinocarveol & 1129 & 1135 & 0.18 & $\mathrm{MS}^{\mathrm{b}}, \mathrm{RI}^{\mathrm{a}}$ \\
5 & 4-Isopropylcyclohexanone & 1142 & 1142 & 0.11 & $\mathrm{MS}^{\mathrm{b}}, \mathrm{RI}^{\mathrm{a}}$ \\
6 & Borneol & 1148 & 1160 & 0.11 & $\mathrm{MS}^{\mathrm{b}}, \mathrm{RI}^{\mathrm{a}}$ \\
7 & Terpinen-4-ol & 1161 & 1174 & 0.07 & $\mathrm{MS}^{\mathrm{b}}, \mathrm{RI}^{\mathrm{a}}$ \\
8 & p-Cymen-8-ol & 1181 & 1179 & 0.18 & $\mathrm{MS}^{\mathrm{b}}, \mathrm{RI}^{\mathrm{a}}$ \\
9 & Cryptone & 1185 & 1183 & 0.27 & $\mathrm{MS}^{\mathrm{b}}, \mathrm{RI}^{\mathrm{a}}$ \\
10 & $\alpha$-Terpineol & 1186 & 1189 & 0.33 & $\mathrm{MS}^{\mathrm{b}}, \mathrm{RI}^{\mathrm{a}}$ \\
11 & Myrtenol & 1195 & 1194 & 0.26 & $\mathrm{MS}^{\mathrm{b}}, \mathrm{RI}^{\mathrm{a}}$ \\
12 & cis-Carveol & 1228 & 1226 & 0.13 & $\mathrm{MS}^{\mathrm{b}}, \mathrm{RI}^{\mathrm{a}}$ \\
13 & Cuminal & 1241 & 1238 & 0.14 & $\mathrm{MS}^{\mathrm{b}}, \mathrm{RI}^{\mathrm{a}}$ \\
14 & 2-Isopropyl-4-methylanisole & 1243 & 1244 & 0.07 & $\mathrm{MS}^{\mathrm{b}}, \mathrm{RI}^{\mathrm{a}}$ \\
15 & D-Carvone & 1244 & 1246 & 0.04 & $\mathrm{MS}^{\mathrm{b}}, \mathrm{RI}^{\mathrm{a}}$ \\
16 & Phellandral & 1257 & 1250 & 0.23 & $\mathrm{MS}^{\mathrm{b}}, \mathrm{RI}^{\mathrm{a}}$ \\
17 & Bornyl acetate & 1285 & 1287 & 0.21 & $\mathrm{MS}^{\mathrm{b}}, \mathrm{RI}^{\mathrm{a}}$ \\
18 & $p$-Thymol & 1289 & 1289 & 1.10 & $\mathrm{MS}^{\mathrm{b}}, \mathrm{RI}^{\mathrm{a}}$ \\
19 & Cumic alcohol & 1292 & 1298 & 0.08 & $\mathrm{MS}^{\mathrm{b}}, \mathrm{RI}^{\mathrm{a}}$ \\
20 & $\alpha$-cubenene & 1342 & 1345 & 0.12 & $\mathrm{MS}^{\mathrm{b}}, \mathrm{RI}^{\mathrm{a}}$ \\
21 & $\gamma$-Pironene & 1350 & 1350 & 0.31 & $\mathrm{MS}^{\mathrm{b}}, \mathrm{RI}^{\mathrm{a}}$ \\
22 & $\beta$-Caryophyllene & 1419 & 1417 & 4.01 & $\mathrm{MS}^{\mathrm{b}}, \mathrm{RI}^{\mathrm{a}}$ \\
23 & 10S,11S-Himachala-3(12),4-diene & 1436 & 1436 & 0.11 & $\mathrm{MS}^{\mathrm{b}}, \mathrm{RI}^{\mathrm{a}}$ \\
24 & $\alpha$-Bergamotene & 1442 & 1440 & 0.83 & $\mathrm{MS}^{\mathrm{b}}, \mathrm{RI}^{\mathrm{a}}$ \\
25 & Humulene & 1448 & 1444 & 1.42 & $\mathrm{MS}^{\mathrm{b}}, \mathrm{RI}^{\mathrm{a}}$ \\
26 & Dihydropseudoionone & 1451 & 1451 & 0.22 & $\mathrm{MS}^{\mathrm{b}}, \mathrm{RI}^{\mathrm{a}}$ \\
& & & & & \\
\hline
\end{tabular}




\begin{tabular}{|c|c|c|c|c|c|}
\hline 27 & allo-Aromadendrene & 1460 & 1458 & 0.18 & $\mathrm{MS}^{\mathrm{b}}, \mathrm{RI}^{\mathrm{a}}$ \\
\hline 28 & $\gamma$-Muurolene & 1479 & 1478 & 0.27 & $\mathrm{MS}^{\mathrm{b}}, \mathrm{RI}^{\mathrm{a}}$ \\
\hline 29 & Germacrene D & 1481 & 1484 & 0.65 & $\mathrm{MS}^{\mathrm{b}}, \mathrm{RI}^{\mathrm{a}}$ \\
\hline 30 & $\beta$-Selinene & 1489 & 1489 & 1.69 & $\mathrm{MS}^{\mathrm{b}}, \mathrm{RI}^{\mathrm{a}}$ \\
\hline 31 & Bicyclogermacrene & 1492 & 1499 & 1.37 & $\mathrm{MS}^{\mathrm{b}}, \mathrm{RI}^{\mathrm{a}}$ \\
\hline 32 & $\alpha$-Muurolene & 1495 & 1500 & 0.20 & $\mathrm{MS}^{\mathrm{b}}, \mathrm{RI}^{\mathrm{a}}$ \\
\hline 33 & 2,2,8,8-tetramethylnona-3,6-diyn-5-one & 1504 & 1504 & 0.16 & $\mathrm{MS}^{\mathrm{b}}, \mathrm{RI}^{\mathrm{a}}$ \\
\hline 34 & (Z)- $\alpha$-Bisabolene & 1507 & 1506 & 0.36 & $\mathrm{MS}^{\mathrm{b}}, \mathrm{RI}^{\mathrm{a}}$ \\
\hline 35 & $\delta$-Selinene & 1508 & 1509 & 0.97 & $\mathrm{MS}^{\mathrm{b}}, \mathrm{RI}^{\mathrm{a}}$ \\
\hline 36 & $\alpha$-Panasinsen & 1512 & 1519 & 1.15 & $\mathrm{MS}^{\mathrm{b}}, \mathrm{RI}^{\mathrm{a}}$ \\
\hline 37 & $\delta$-Cadinene & 1523 & 1522 & 2.00 & $\mathrm{MS}^{\mathrm{b}}, \mathrm{RI}^{\mathrm{a}}$ \\
\hline 38 & $\begin{array}{l}\text { 1,6-Dimethyl-4-(1-methylethyl)-1,2,3,4,4a,7- } \\
\text { hexahydronaphthalene }\end{array}$ & 1547 & 1546 & 0.93 & $\mathrm{MS}^{\mathrm{b}}, \mathrm{RI}^{\mathrm{a}}$ \\
\hline 39 & Nerolidol & 1563 & 1563 & 1.31 & $\mathrm{MS}^{\mathrm{b}}, \mathrm{RI}^{\mathrm{a}}$ \\
\hline 40 & Spathulenol & 1567 & 1577 & 27.63 & $\mathrm{MS}^{\mathrm{b}}, \mathrm{RI}^{\mathrm{a}}$ \\
\hline 41 & Caryophyllene oxide & 1582 & 1582 & 2.27 & $\mathrm{MS}^{\mathrm{b}}, \mathrm{RI}^{\mathrm{a}}$ \\
\hline 42 & Ledol & 1605 & 1602 & 6.81 & $\mathrm{MS}^{\mathrm{b}}, \mathrm{RI}^{\mathrm{a}}$ \\
\hline 43 & (-)-Humulene epoxide II & 1608 & 1608 & 2.32 & $\mathrm{MS}^{\mathrm{b}}, \mathrm{RI}^{\mathrm{a}}$ \\
\hline 44 & $\beta$-Spathulenol & 1618 & 1619 & 0.25 & $\mathrm{MS}^{\mathrm{b}}, \mathrm{RI}^{\mathrm{a}}$ \\
\hline 45 & Caryophylladienol I & 1639 & 1639 & 1.97 & $\mathrm{MS}^{\mathrm{b}}, \mathrm{RI}^{\mathrm{a}}$ \\
\hline 46 & Alloaromadendrene oxide I & 1641 & 1641 & 0.12 & $\mathrm{MS}^{\mathrm{b}}, \mathrm{RI}^{\mathrm{a}}$ \\
\hline 47 & $\delta$-Cadinol & 1646 & 1644 & 2.05 & $\mathrm{MS}^{\mathrm{b}}, \mathrm{RI}^{\mathrm{a}}$ \\
\hline 48 & $\beta$-Eudesmol & 1650 & 1649 & 2.55 & $\mathrm{MS}^{\mathrm{b}}, \mathrm{RI}^{\mathrm{a}}$ \\
\hline 49 & $\alpha$-Cadinol & 1652 & 1652 & 3.24 & $\mathrm{MS}^{\mathrm{b}}, \mathrm{RI}^{\mathrm{a}}$ \\
\hline 50 & (+)-cis-Limonene oxide & 1660 & 1660 & 3.69 & $\mathrm{MS}^{\mathrm{b}}, \mathrm{RI}^{\mathrm{a}}$ \\
\hline 51 & Longifolenaldehyde & 1668 & 1668 & 0.09 & $\mathrm{MS}^{\mathrm{b}}, \mathrm{RI}^{\mathrm{a}}$ \\
\hline 52 & (Z)-4-Hexadecen-6-yne & 1687 & 1687 & 0.15 & $\mathrm{MS}^{\mathrm{b}}, \mathrm{RI}^{\mathrm{a}}$ \\
\hline 53 & $(E, E)$-Farnesol & 1742 & 1742 & 0.11 & $\mathrm{MS}^{\mathrm{b}}, \mathrm{RI}^{\mathrm{a}}$ \\
\hline 54 & 6,10,14-Trimethyl-2-pentadecanone & 1847 & 1847 & 0.20 & $\mathrm{MS}^{\mathrm{b}}, \mathrm{RI}^{\mathrm{a}}$ \\
\hline 55 & Methyl hexadecanoate & 1921 & 1922 & 0.10 & $\mathrm{MS}^{\mathrm{b}}, \mathrm{RI}^{\mathrm{a}}$ \\
\hline 56 & Diisobutyl phthalate & 1940 & 1940 & 0.21 & $\mathrm{MS}^{\mathrm{b}}, \mathrm{RI}^{\mathrm{a}}$ \\
\hline 57 & $(E, E, E)$-Geranylgeraniol & 2009 & 2009 & 0.33 & $\mathrm{MS}^{\mathrm{b}}, \mathrm{RI}^{\mathrm{a}}$ \\
\hline 58 & Luciferin aldehyde & 2113 & 2113 & 0.07 & $\mathrm{MS}^{\mathrm{b}}, \mathrm{RI}^{\mathrm{a}}$ \\
\hline 59 & n-Octadecanoic acid methyl ester & 2124 & 2124 & 0.12 & $\mathrm{MS}^{\mathrm{b}}, \mathrm{RI}^{\mathrm{a}}$ \\
\hline 60 & 13-Tetradecen-1-yl acetate & 2135 & 2137 & 0.05 & $\mathrm{MS}^{\mathrm{b}}, \mathrm{RI}^{\mathrm{a}}$ \\
\hline 61 & 14-Methyl-8-hexadecyn-1-ol & 2341 & 2341 & 0.09 & $\mathrm{MS}^{\mathrm{b}}, \mathrm{RI}^{\mathrm{a}}$ \\
\hline 62 & $\begin{array}{l}\text { Octanedioic acid, 2-undecyl-1,8-dimethyl-ester } \\
\text { Total }\end{array}$ & 2354 & 2354 & $\begin{array}{c}0.07 \\
76.45\end{array}$ & $\mathrm{MS}^{\mathrm{b}}, \mathrm{RI}^{\mathrm{a}}$ \\
\hline
\end{tabular}

\#Compounds are listed in order; RI, retention indices relative to n-alkanes (C8-C30) series on the DB-1 MS column; RI*, retention index from literature; MS, mass spectroscopy; ${ }^{\mathrm{c}}$ The content $(\%)$ of the individual components was calculated based on the peak area (FID response).

Herein, we were reported the chemical composition of the essential oil of the leaves of $L$. fragrans for the first time. Nearly half $(47.87 \%)$ of the identified compounds were determined as alcohols and $25.13 \%$ of them as olefins of the essential oil. Among twenty two different kinds of alcohols type compounds spathulenol, ledol, $\alpha$-cadinol, $\delta$-cadinol and $\beta$-eudesmol are found to be most abundant ones. Apart from those, a hydrocarbon sesquiterpene $\beta$-caryophyllene was found as relatively high ratio $(4.01 \%)$ in the essential oil.

Chemotaxonomic evaluation was done by a comprehensive investigation of reported literature on the Lindera species and compared with our data. Similar components and percentages were reported from $L$. chunii and L. glauca which are spathulenol, $\beta$-selinene, $\gamma$-muurolene, germacrene D and ledol $[7,8,10]$. Those data confirms the close chemotaxonomic relations between the species $L$. fragrans, $L$. chunii and L. glauca. On the other hand, when we compared with published data of $L$. neesiana and the L. nacusua, the major compounds were also determined as terpinen-4-ol, spathulenol and $\beta$-selinene, spathulenol, methyl hexadecanoate, respectively $[4,9]$. 
Spathulenol exists widely in the genus Lindera, including L. neesiana (1.66\%), L. nacusua (1.41\%), L. setchuenensis (23.2\%), L. glauca (0.05\%) and L. chunii (3.3\%). And the content of spathulenol reaches a maximum in L. fragrans with $27.63 \%$. Besides the genus Lindera, some plants essential oil in which spathulenol as a major compound possess some biological activities including antiproliferative, anti-inflammatory, antimicrobial and so on [14]. Spathulenol proved to be highly effective biting deterrents against $A$. stephensi and A. aegypti [15]. The spathulenol was also the major constituent of the essential oil of Psidium guineense Sw. and inhibited M. tuberculosis at the MIC values of $231.9 \mu \mathrm{g} / \mathrm{mL}$ [16]. Another report delivered that spathulenol was a good candidate to be used in combination chemotherapy of MDR cancer [17]. We can clearly say that the amount oxygenated sesquiterpenoid spathulenol is differentiate in the genus, and the title species can be considered as spathulenol chemotype species. The other main compound $\beta$-caryophyllene, as active ingredient, widely exists in essential oil of plant species and its amount was found to be rich in $L$. erythrocarpa and $L$. chunii. Previous pharmacological studies have shown that the $\beta$-caryophyllene had the effects of anti-inflammatory, anti-anxiety and anti-depression [18, 19]. A separate study found $\beta$ caryophyllene appeared to be effective against An. subpictus, Ae. albopictus and $C x$. Tritaeniorhynchus and promised to be eco-friendly larvicides against malaria [20].

Antimicrobial Activity Test: Method employed in the tests was given [21]in supporting information S2.The essential oil of L. fragrans leaf exhibited inhibition effect against Staphylococcus aureus, Escherichia coli, and Candida albicans with the inhibition zone at 8.31, 7.52, $7.69 \mathrm{~mm}$, respectively, compared with that of amoxicillin all at $7.00 \mathrm{~mm}$. While the essential oil of L. fragrans leaf reveals no obvious bacteriostasis for Pseudomonas aeruginosa. These results reveal the new potential application of $L$. fragrans in the treatment of some infection diseases.

Antioxidant Activity Test: Method employed in the tests was given [22] in supporting information S3.The antioxidant capacity of $L$. fragrans essential oil was presented in Table 2 . We found that the essential oil possessed weak antioxidant activity against DPPH with the $\mathrm{IC}_{50}$ values of $33.01 \mathrm{mg} / \mathrm{mL}$, lower than trolox with the $\mathrm{IC}_{50}$ values of $23.33 \mathrm{mg} / \mathrm{mL}$. However, no obvious antioxidant activity was found in the ABTS assay and $\beta$-Carotene bleaching assay.

Table 2. Antioxidant potential of the essential oil from the leaves of L. fragrans a

\begin{tabular}{llll}
\hline & Essential oil & BHA & Trolox \\
\hline DPPH $\left(\mathrm{IC}_{50} \mathrm{mg} / \mathrm{mL}\right)$ & $33.01 \pm 2.77$ & $0.0062 \pm 0.00030$ & $23.33 \pm 0.92$ \\
ABTS $\left(\mathrm{IC}_{50} \mathrm{mg} / \mathrm{mL}\right)$ & $7.73 \pm 3.61$ & $0.023 \pm 0.0074$ & $0.051 \pm 0.0013$ \\
$\beta$-Carotene bleaching $\left(\mathrm{IC}_{50} \mu \mathrm{L} / \mathrm{mL}\right)$ & $28.94 \pm 8.35$ & $0.019 \pm 0.0028$ & $4.2 \pm 0.89$ \\
\hline \multicolumn{2}{l}{ a Values expressed are means \pm SD of three parallel measurements (p<0.05). }
\end{tabular}

As a conclusion, this is the first report on the chemical composition of leaf essential oil of $L$. fragrans. The species was determined as a spathulenol chemotype and it may be considered as a new source of spathulenol. While the essential oil showed remarkable antimicrobial activity, it did not show effective antioxidant activity.

\section{Acknowledgments}

The authors are grateful to the members of the analytical group of Chengdu Institute of Biology, Chinese Academy of Sciences, for the GC and GC-MS measurements. And this work was supported by the Fundamental Research Funds for the Central Universities, the research project of the Fund of Science and Technology Agency of Chengdu (No. 2019-YF09-00049SN), the Open Project Program of Irradiation Preservation Technology Key Laboratory of Sichuan Province, Sichuan Institute of Atomic Energy (No. FZBC2020002), the Administration of Traditional Chinese Medicine of Sichuan (2017PC004), and the $14^{\text {th }}$ Personalized Experimental Project (GX202013085 and GX202013100). 


\section{Supporting Information}

Supporting Information accompanies this paper on http://www.acgpubs.org/journal/recordsof-natural-products

\section{ORCID}

Chunyan Du: 0000-0001-9913-9114

Yanan Li: 0000-0001-5037-7330

Junting Fan: 0000-0002-0242-294X

Rui Tan: 0000-0002-7795-1141

Hezhong Jiang: 0000-0002-7990-3952

\section{References}

[1] Z. Deng, H. Zhong, S. Cui, F. Wang, Y. Xie and Q. Yao (2011). Cytotoxic sesquiterpenoids from the fruits of Lindera communis, Fitoterapia. 82, 1044-1046.

[2] Y. Chen (2011). Standard of Traditional Chinese Medicine in Sichuan Province. Science Technol Press, Chengdu, China, pp. 218-220.

[3] G. Q. Wei, H. Chen, L. Kong, X. R. Li, C. Y. Ma and H. Z. Jiang (2016). Composition and bioactivity of the essential oil from the leaves of Lindera setchuenensis, Chem. Nat.Compd. 52, 520-522.

[4] G. Q. Wei, L. Kong, J. S. Zhang, C. Y. Ma and H. Z. Jiang (2016). Essential oil composition and antibacterial activity of Lindera nacusua (D. Don) Merr, Nat. Prod. Res. 30 (23), 2704-2706.

[5] Y. J. Ko, G. Ahn and Y. M. Ham (2017). Anti-inflammatory effect and mechanism of action of Lindera erythrocarpa essential oil in lipopolysaccharide-stimulated RAW264.7 cells, Excli. J. 16, 1103-1113.

[6] Z. L. Liu, S. S. Chu, J. C. Hong, J. Hou, Q. Z. Liu and G. H. Jiang (2016). Composition and insecticidal activity of the essential oil of Lindera aggregata root tubers against Sitophilus zeamais and Tribolium castaneum, J. Essent. Oil Bear. Plants. 19, 727-733.

[7] B.Q. Zhu, X. Y. Hou, J. Niu, P. X. Li, C. L. Fang, L. Qiu, D. L. Ha, Z. X. Zhang, J. Q. Sun, Y. B. Li and S. Z. Lin (2016). Volatile constituents from the fruits of Lindera glauca (Sieb. et Zucc.) with different maturities, J. Essent. Oil Bear. Plants. 19, 926-935.

[8] T. Guo, Z. W. Wu, X. T. Shen, W. Z. Ni and X. J. Pan (2011). Analysis of the constituents of the volatile oil from the leaf of Lindera Glauca (Sieb.et Zucc.) BL. from Zhejiang, Strait. Pharm. 23, 4648.

[9] S. Comai, S. Dall'acqua, A. Grillo, I. Castagliuolo, K. Gurung and G. Innocenti (2010). Essential oil of Lindera neesiana fruit: Chemical analysis and its potential use in topical applications, Fitoterapia 81, 11-16.

[10] Y. Q. Liu, H. W. Wang, S. L. Wei and X. Cai (2013). Characterisation of the essential oil from different aerial parts of Lindera chunii Merr. ( Lauraceae), Nat. Prod. Res. 27, 1804-1807.

[11] R. W. Yan, Y. Yang and G. L. Zou (2014). Cytotoxic and apoptotic effects of Lindera strychnifolia leaf essential oil, J. Essent. Oil Res. 26, 308-314.

[12] R. W. Yan, Y. Yang, Y. Y. Zeng and G. L. Zou (2009). Cytotoxicity and antibacterial activity of Lindera strychnifolia essential oils and extracts, J. Ethnopharmacol. 121, 451-455.

[13] H. Maeda, M. Yamazaki and Y. Katagata (2012). Kuromoji (Lindera umbellata) essential oil-induced apoptosis and differentiation in human leukemia HL-60 cells, Exp. Ther. Med. 3, 49-52.

[14] H. Bendaoud, M. Romdhane, J. P. Souchard, S. Cazaux and J. Bouajila (2010). Chemical composition and anticancer and antioxidant activities of Schinus Molle L. and Schinus Terebinthifolius Raddi berries essential oils, J. Food Sci. 75, 466-472.

[15] C. L. Cantrell, J. A. Klun, C. T. Bryson, M. Kobaisy and S. O. Duke (2005). Isolation and identification of mosquito bite deterrent terpenoids from leaves of American (Callicarpa americana) and Japanese (Callicarpa japonica) beautyberry, J. Agric. Food Chem. 53, 5948-5953.

[16] K. F. Do Nascimento, F. M. F. Moreira, J. A. Santos, C. A. L. Kassuya, J. H. R. Croda, C. A. L. Cardoso, M. D. C. Vieira, A. L. T. Gois Ruiz, M. Ann Foglio, J. E. De Carvalho and A. S. N. Formagio (2018). Antioxidant, anti-inflammatory, antiproliferative and antimycobacterial activities of the essential oil of Psidium guineense Sw. and spathulenol, J. Ethnopharmacol. 210, 351-358. 
[17] A. Martins, Z. Hajdu, A. Vasas, B. Csupor-Loeffler, J. Molnar and J. Hohmann (2010). Spathulenol inhibit the human ABCB1 efflux pump, Planta Med. 76, 1349-1349.

[18] R. H. Basha and C. Sankaranarayanan (2016). beta-Caryophyllene, a natural sesquiterpene lactone attenuates hyperglycemia mediated oxidative and inflammatory stress in experimental diabetic rats, Chem. Biol. Interact. 245, 50-58.

[19] P. M. Galdino, M. V. Nascimento, I. F. Florentino, R. C. Lino, J. O. Fajemiroye, B. A. Chaibub, J. R. De Paula, T. C. De Lima and E. A. Costa (2012). The anxiolytic-like effect of an essential oil derived from Spiranthera odoratissima A. St. Hil. leaves and its major component, beta-caryophyllene, in male mice, Prog. Neuro-Psychopharmacol. Biol. Psychiatry. 38, 276-284.

[20] M. Govindarajan, M. Rajeswary, S. L. Hoti, A. Bhattacharyya and G. Benelli (2016). Eugenol, $\alpha$-pinene and $\beta$-caryophyllene from Plectranthus barbatus essential oil as eco-friendly larvicides against malaria, dengue and Japanese encephalitis mosquito vectors, Parasitol. Res. 115, 807-815.

[21] A. Baldemir, B. Demirci, M.Y. Paksoy, S. İlgün, M. Koşar, K. H. C. Başer and F. Demirci (2018). Chemical composition of the essential oil and antimicrobial activity of Scaligeria DC. taxa and implications for taxonomy, Rec.Nat.Prod. 12, 14-28.

[22] F. Diwan, M.H. Shaikh, M. Shaikh and M. Farooqui (2019). $\gamma$-Valerolactone: Promising biocompatible media for the synthesis of 2-arylbenzothiazole derivatives, Org.Commun.12,1-13.

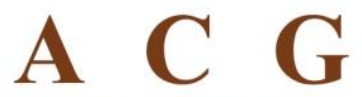

publications

(C) 2020 ACG Publications 